\title{
The Guidance and Counseling Management Programs at Senior High School
}

\author{
Doni Yulianto, Warih Handayaningrum, Karwanto \\ Magister Educational Management \\ Universitas Negeri Surabaya \\ Surabaya, Indonesia \\ doniauliyaa06@gmail.com
}

\begin{abstract}
This study aims to determine the management of guidance counseling service programs that include planning, implementing and evaluating. This study used a qualitative case study method with a multisite research design. In this research, data collected using interviews, observations, and documentation method. Data were analyzed using Miles and Huberman's technique. The results of this study include planning the guidance and counseling program according to the planning procedure approved by the school, and it contains a clear vision of objective. The implementation of guidance programs cover, among others, working with various parties, flexible time, and using various types of counseling techniques. In program evaluation can be seen from the achievement of program planning.
\end{abstract}

Keywords-management program; planning; implementing; evaluating; senior high school

\section{INTRODUCTION}

In improving human resources, education is often used as an investment to succeed the National Development of the Indonesian Nation. Refers to with Law No. 20 of 2003 concerning the National Education System article 1 paragraph 1.The large number of Indonesian people who take education is often used as a measure to evaluate the success of Indonesian nation education. Besides that, the benchmark for the success of education in Indonesia is measured by average academic score. In other words where schools that get high scores are considered to have an achievement in the successful implementation of education.

In the school, students as human beings are always face problems. Some students are able to, and resilient to, face these problems, while some others are giving up and despair in dealing with these problems.

Therefore, in helping to deal with students' problems, preventive action is needed through giving direction and guidance to students so that they do not go deeper into actions that violate the rules and norms of the community. The effort carried out in the school environment is the establishment of a special service for students who need help and provides them with trainings in improving their problem solving skills. The service can be packaged in the forms of guidance and counseling services.

Guidance and counseling services are two forms of activities that cannot be separated. Mulyadi argues that guidance is a form of assistance that is carried out continuously and systematically to individuals in solving problems they face, so they can understand themselves (selfunderstanding), are able to accept themselves themselves (self-acceptance), are able to direct themselves (self direction) and able to realize itself (self-realization) in accordance with the potential and ability to adapt to the environment, family and society [1].

In addition to improving student adaptability Pamela Awour said [2] that $68.06 \%$ agreed that effective guidance and counseling shapes positive behavior for students, strengthens self-concept and self-esteem of students, and makes them to be more positive in their environments.

Theaim of counseling services is to make school guidance programs tailored to the problems of students. Therefore, an effort is needed to optimize so that the program services run according to their objectives. The findings of Jarkawi's study show that a management program in guidance and counseling services was needed at the Banjarmasin vocational school [3].

Guidance and counseling management, according to Syamsu [4], is a system which is an organizational process and tool needed to manage guidance and counseling programs in schools. This system is associated with the concepts of "when, why, by whom and what auditory" when the guidance and counseling program is launched.

Likewise, Tohirin [5] also suggested that guidance and counseling management is a series of processes of planning, organizing, directing and supervising all activities of guidance and counseling services as well as the use of other resources to achieve predetermined goals.From the definition above, the elements that build in guidance and counseling management are planning, implementing and evaluating counseling programs.

In connection with the implementation of guidance and counseling a study conducted by Rachmawati [6] found that the implementation of a guidance and counseling program that provided information services was only conducted for classes $\mathrm{X}$ and XII, as well as the provision of classical services which were only given when urgent and unscheduled would be very risky and difficult to account for. The service coverage of guidance and counseling is narrow, and the evaluation of successful service programs is difficult to do.

The existence of guidance and counseling programs in high schools is a form of integrity in achieving national 
education goals. Implementation guidance and counseling programs in senior high school 10 Surabaya (SMAN 10 Surabaya) are realized with twenty card days (TCD) program, career guidance programs. Therefore, we need a counseling management so that the guidance and counseling program can run effectively and efficiently. The designer will need to create these components, incorporating the applicable criteria that follow.

The focus of this research is guidance and counseling management programs including planning, implementing and evaluating classical guidance programs, peer guidance programs, TCD (twenty care day) programs and career guidance programs at senior high school.

The purpose of this study is to determine the management of guidance counseling service programs that include planning, implementing and evaluating.

\section{METHOD}

This study used a qualitative approach. According to Moeloeng, a qualitative approach is a form of research work flow with inductive, holistic and process oriented. This study iwas a case study with multisite design.

A case study, according to Yin, is a type of empirical research that investigates phenomena in real life and utilizes multiple sources as evidence [7]. Meanwhile, according to Bogdan and Biklen, multi-site design is a form of qualitative research design to develop selected theories from several similar backgrounds [8].

This research was conducted at two senior high school, which had the same character such as level equality, urban location conditions and school status are the same as state schools. For data collection using observation, interviews and documentation. After the data is collected, the data validity will be carried out using credibility, transferbility, dependability and confirmation, which will then be analyzed using the Miles and Hubberman model analysis [9] a way that is done by working with data, organizing data, sorting data, synthesizing data, searching and finding patterns.

\section{RESULTS AND DISCUSSION}

\section{A. Planning of guidance and counseling management programs.}

According to the operational guidelines for the implementation of high school guidance and counseling [10], the counseling planning stage is divided into two, namely the preparation and design stages. In the preparation phase consists of needs assessment, school support and basic planning, as well as in the design phase consisting of the preparation of the annual program, formulation of the activity matrix and follow-up based on the activity schedule.

Special counseling services at state senior high school 10 Surabaya (SMAN 10 Surabaya) provide several programs such as classical guidance and peer guidance programs. Classical guidance is a type of counseling service program that provides guidance material by counselors in the classroom according to the schedule. While peer guidance is a form of guidance given to students with the aim that students can help each other if the participants have a problem.

The planning made by the SMAN 10 Surabaya counselor is an assessment of the needs of students. The students of SMAN 10 Surabaya are middle adolescents, who will experience physical, psychological, moral and social changes. For this reason, special material is needed about the physical, psychological, moral and social changes given by the counselor to students while in the classroom through classical guidance. The students can know the danger and can fortify themselves from moral, social and cultural degradation.

The program is also supported by the school. The proof is the headmaster of senior high school gave a policy to counselors for 1 lesson for classical guidance. In the design phase, the counselor makes a planning plan written in the service plan of guidance and counseling, annual program, semester program and Follow-up Plan.

The next program is peer guidance. This is based on the following which was conveyed by counselor of SMAN 10 Surabaya.

"This program is there to help students empathize and sympathize with each other, especially students with special needs. Because at the school this also accepts students with special needs. With the existence of peer guidance, I hope there will be no discrimination, and these special students can get educational services like other students. "

The special counseling service program at state senior high school 20 Surabaya (SMAN 20 Surabaya) is twenty care day (TCD) cards and mapping programs in career guidance. Twenty care day (TCD) card is a counseling service program carried out by giving class teachers a card to record student violations during learning in the classroom. The card will be given to the counselor after the learning is complete. It is expected that with this program, all teachers care about violations committed by students.

The researchers' findings in the planning of the TCD card program based on by coordinator the guidance and counseling SMAN 20 Surabaya teacher. Beginning at the meeting, counselor had an idea to curb the high level of violations at SMAN 20 Surabaya. The counselor's idea was realized through a card. This is due to the fact that Ms. Yanti, who is approaching her retirement period, will lose if all violations are delegated to 3 counselors at SMAN 20 Surabaya. The counselor also wants the existence of this program, all the teachers are also active to curb violations committed by students of SMAN 20 Surabaya.

This TCD card program is in the design stage, there is no special technical guidance contained in the plan for implementing counseling services, but it is included in the annual program and and semester program and will be given follow up plan as accountability.

The mapping program in career guidance. "This mapping program was taken as an anticipation step in responding to the confusion of class XII students who were confused about choosing a department to continue their education to college. Because at SMAN 20 Surabaya there is no specific policy for 
teaching hours in the classroom. So counselor took the Craft teacher's hour once every hour at the beginning of the month ".

Therefore, the planning of this program is the initiative of the counselor based on the policy of the head of SMAN 20 Surabaya. In this school not have anydoes guidance hours in a class that is different from the policy at SMAN 10 Surabaya. This is in accordance with Rahman [11] resulting in planning in guidance and counseling management in Jambi City Senior High Schools still paying attention to the school situation, face to face policies, facilities and budget.

The mapping program at SMAN 20 Surabaya, it is not written in the service plant of guidance and counseling but is still written in the annual program and semester programs of guidance and counseling services at SMAN 20 Surabaya. So the implementation of this program is more flexible, carried out in collaboration with all school parties and using facilities and infrastructure that support counseling and guidance services.

\section{B. Implementation of guidance and counseling management programs}

After the planning phase, the next stage is the implementation stage. Programs that have been planned will be carried out according to the plan. This is in accordance with the findings of Fenti planning is the stage of actualization, implementation of all programs, types of services and activities that have been carefully planned [12].

In connection with the implementation of guidance and counseling, in a study conducted by Rachmawati [13], the implementation of a guidance and counseling program that provided information services only for classes X and XII, as well as the provision of classical services which were only given when urgent and unscheduled would be very risky and difficult to account for. Service coverage Guidance and counseling is narrow and evaluation of program success is difficult to do.

The findings of the researchers in the implementation of the classical guidance program at state senior high school, this program is carried out routinely at every guidance and counseling learning hour, the material and implementation procedures are neatly arranged in accordance with existing learning tools and service plan of guidance and counseling, the school cooperates with counselors by providing 1 hour guidance and counseling in class.

For the researchers' findings on the implementation of peer guidance programs at SMAN 10 Surabaya, like as this program is incidental, this peer guidance program requires collaboration between counselors, regular students, students with special needs to understand and respect each other as regular students should not discriminate against students with needs specifically and special needs students may not be inferior or discouraged to socialize with regular students.

For the researchers' findings on the implementation of special services for the twenty care day (TCD) card program, like as, this program is continuously carried out every day when subject teachers will enter the class, must carry a TCD card according to the color and grade level, this program requires collaboration between teachers subjects, counselors and the school, this program is flexible and the program's reward program, for subject teachers who provide the most violation records at the end of the report will be given prizes.

The researchers 'findings on the implementation of special services for career guidance mapping programs include flexible programs that do not force students to enter courses in the desired direction of private parties rather than students' wishes, are incidental because they are only conducted once a month at the beginning of the week, this program requires work same between counselors, students and parents.

From the findings of the implementation of a special counseling service program in both locations, according to the findings of the statement from Dedi [10] which stated that the implementation of good guidance and counseling services included implementing various types of services and supporting activities that had been planned, using various techniques, approaches or counseling methods in guidance and counseling services, collaborative work, collaboration with various parties related to guidance and counseling services; managing facilities and infrastructure in the implementation of guidance and counseling services

\section{Evaluation of guidance and counseling management programs}

Evaluation according to the findings from Anjar [14] is a way to get information regularly, continuously, and thoroughly about the process and results of student development through a program that has been implemented.

According to Syamsu [4], the purpose of the evaluation is to obtain data in order to make important decisions about the structure of the program and its development in the future. When the guidance and counseling program has been completed, the last step is to conduct an evaluation. With this stage, the counselor can assess whether this guidance and counseling program can be continued or not and as proof of the form of accountability to the coordinator of the supervising teacher and the principal.

lmawijaya [15] states that the evaluation of guidance and counseling programs can be seen in short term reports, long term reports and program implementation reports covering the number of times the program is implemented until the follow up process. The report activity will be reported by the counselor every semester to the principal as the responsibility of implementing the programs guidance and counseling

The researchers' findings about the evaluation of the classical guidance program conducted by counselors at SMAN 10 Surabaya, are in the form of reports each semester to the guidance and counseling coordinator and the principal that classical guidance services have been carried out. In addition, according to the counselor of SMAN 10 Surabaya, with this classical guidance, counselors can find out the group dynamics of each class, can know the problems faced by students correctly and quickly.

The researchers' findings about the evaluation of peer guidance programs at SMAN 10 Surabaya are the absence of written reports from peer guidance, because this program is 
incidental and is part of the implementation of group guidance. However, the effectiveness of this program can be seen from the reduced report on the negative actions of regular students on students with special needs.

The findings of researchers on the TCD card program at SMAN 20 Surabaya, among others, are written reports as the responsibility of the supervising teacher coordinator to the principal at the end of each month. The report is in the form of notes on the names of subject teachers as reporters, names of students and forms of violations as well as the number of those who report the most violations will be given special rewards as an appreciation that all schools care about discipline and order in students.

The researchers 'findings on the evaluation of the mapping program in class XII career guidance services at senior high school included a specialization sheet for the students' majors, a sheet of reasons and priority for majors, a mapping sheet for department choice for SBMPTN registration and proof of SBMPTN registration. After that the form of the report is in the form of the results of students who are accepted into the invitation path of the SBMPTN as a measure of success. In 2018 , almost $80 \%$ of the SBMPTN registration quota, SMAN 20 Surabaya students can enter in accordance with the direction they

\section{CONCLUSION}

Based on the results of the research described above, some conclusions can be drawn as follows.

a) planning classical guidance programs, peer guidance TCD (twenty care day) card programs, mapping programs in career guidance at Senior High School according to planning procedures using assessment of student needs and getting approval from the school.

b) the implementation of classical guidance programs, peer guidance, TCD card programs, mapping programs in career guidance at Senior High School, according to procedures for implementing guidance and counseling programs, namely working with various parties, being flexible, and using various types of counseling techniques.

c) evaluation of classical guidance programs, peer guidance at senior high school, namely monthly, semester and annual reports, planned follow-up and reduced levels of discrimination to students with special needs. Whereas the evaluation for the TCD card program and career guidance mapping is the accountability report to the principal and the increasing percentage of successful students in their careers and graduating from the SBMPTN at the targeted state universities.

\section{REFERENCES}

[1] Mulyadi, Diagnosis Kesulitan Belajar dan Bimbingan Terhadap Kesulitan Belajar Khusus. Yogyakarta: Nuha Llitera, 2010.

[2] Onyango, and Raburu, "Effectiveness of Guidance and Counseling in the Public Secondary Schools in Kenya," International Journal of Applied Psychology, vol. 8, pp. 8, 2018.

[3] Jarkawi, K. Anwar, Z. Fauzi, and H. Maidah, "The Study About Management of Counseling and Guidance Progam in Vocational School Banjarmasin Indonesia," International Research Based Education, pp. 182-187, 2017.

[4] S. Yusuf and J. Nurihsan, Landasan Bimbingan dan Konseling. Bandung: PT Remaja Rosdakarya, 2016.

[5] Tohirin, Bimbingan dan Konseling di Sekolah dan Madrasah. Jakarta: Pt Raja Grafindo Persada, 2007.

[6] U. Rachmawati, Nusantoro, E., Kurniawan, K, "Manajemen Bimbingan dan Konseling Tanpa Alokasi Jam Pembelajaran di SMAN 3 Semarang," Indonesian Jurnal of Guidance and Counseling Theory Application, vol. 2, pp. 55-61, 2013.

[7] Yin, Case Study Research : design and methods. California Sage Publication, 2004.

[8] R. Bogdan and S. K. Biklen, Qualitatif research for education: and introduction to theory and methods. Boston: Allyn \& bacon Inc, 1982.

[9] B. Mattew, A. Miles, and M. Huberman, Qualitative Data Analisys A Sources Book of New Method Baverly Hill Sage Publication, 1984.

[10] Rahman, M. Muhammad, and M. Titin, "Manajemen Bimbingan dan Konseling di SMAN Jambi," Administrasi Pendidikan, vol. XXIV, pp. 41, 2017.

[11] T. Ratnawulan and S. A. Rahman, "Management Profil of Guidance and Counseling in Junior High School," International Journal of Social Science, pp. 334-350, 2017.

[12] F. Hikmawati, Bimbingan dan Konseling. Jakarta: Rajawali Press, 2014.

[13] Rachmawati, Nusantoro, and Kurniawan, Manajemen Bimbingan dan Konseling Tanpa Alokasi Jam Pembelajaran di SMAN 3 Semarang. Indonesian Jurnal of Guidance and Counseling Theory Application 2, Vol 1, pp.55-61, 2013.

[14] T. Anjar, "Task and Manajement Supervision of Guidance and Counseling," Journal Guidance and Counseling (Guidena), vol 4, pp. 22-34, 2014

[15] H. Almawijaya, "Analisis Manajemen Bimbingan dan Konseling dalam Peningkatan Prestasi Belajar Siswa," Jurnal Manajemen Pendidikan, vol 6, pp. 618-628, 2015. 